\title{
ANALISIS IMPLEMENTASI PRINSIP-PRINSIP GOOD CORPORATE GOVERNANCE (GCG) PADA PT. BANK MANDIRI (PERSERO) TBK. CABANG BENGKULU
}

\author{
Sukandi \\ Email: sukandiandi44@yahoo.com \\ Tito Irwanto \\ Email: tito.irwato22@gmail.com \\ Meiffa Herfianti \\ Email: meiffaherfianti@gmail.com \\ Fakultas Ekonomi Universitas Dehasen Bengkulu
}

\begin{abstract}
The objective of this research is to Implementation of the good corporate governance (GCG) principles in addition to improving bank competitiveness itself, also provide more protection to the community. The implementation of the good corporate governance (GCG) principles becomes a trust given the banking industry that manages public funds (customers). The objective of this research is to know the analysis implementation of good corporate governance (GCG) principles in PT. Bank Mandiri (Persero) Tbk. Branch of Bengkulu. The object of this research is permanent employee of PT. Bank Mandiri (Persero) Tbk Branch Office of Bengkulu which amounted to 67 people, with sampling method that is total sampling. The sources of data in this study through questionnaires. The data analysis technique used quantitative descriptive analysis with mean method and frequency distribution table. The results of this study research that, implemtasi good corporate governance (GCG) principles at PT. Bank Mandiri (Persero) Tbk. Branch of Bengkulu has been running well with the average value of the statement 3.77 (good). Furthermore, the implementation principles of transparency, accountability, responsibility, independence and fairness have gone well with the average value each statement of 3.71 (good), 3.86 (good), 3.76 (good), 3.67 (good), 3.86 (good).
\end{abstract}

Keyword: governance, bank, competitiveness.

\section{PENDAHULUAN}

Pada dasarnya implementasi prinsip-prinsip good corporate governance (GCG) pada lembaga perbankan menjadi sebuah keharusan karena aset fisik dari 
perbankan adalah nasabahnya, sehingga perbankan harus menjaga kepercayaan nasabah bahwa dana yang tersimpan akan dikelola dengan baik dan aman. Anshori (2007) menyatakan bahwa pelaksanaan good corporate governance (GCG) pada industri perbankan harus senantiasa berlandaskan pada lima prinsip dasar, transparansi (transparency), akuntabilitas (accountability), pertanggungjawaban (responsibility), independensi (independency) dan kewajaran (fairness). Sebagai lembaga intermediasi dan lembaga kepercayaan, dalam melaksanakan kegiatan usahanya bank harus menganut prinsip keterbukaan (transparacy), memiliki ukuran kinerja dari semua jajaran bank berdasarkan ukuran-ukuran yang konsisten dengan corporate value, sasaran usaha dan strategi bank sebagai pecerminan akuntabilitas bank (accountability), berpegang pada prudential banking practices dalam menjamin dilaksanakannya ketentuan yang berlaku sebagai wujud tanggung jawab bank (responsibility), objektif dan bebas dari tekanan pihak manapun dalam penambilan keputusan (independency), serta senantiasa memperhatikan stakeholders berdasarkan azas kesetaraan dan kewajaran (fairness). Oleh sebab itu dalam penerapan good corporate governance (GCG) suatu perbankan harus melaksanakan prinsip-prinsip tersebut.

Penelitian ini akan dilakukan pada perusahaan PT. Bank Mandiri (Persero) Tbk sebagai salah satu perusahaan BUMN pada industri perbankan dan sebagai perusahaan yang menerapkan prinsip good corporate governance (GCG) dalam menjalankan sistem bisnisnya sehingga isu good corporate governance (GCG) dalam perusahaan ini tentunya masih hangat. PT. Bank Mandiri (Persero) Tbk terus berupaya menerapkan praktik terbaik good corporate governance (GCG) dengan mematuhi peraturan perundangundangan yang berlaku serta melakukan perbaikan dan penyempurnaan pengelolaan good corporate governance (GCG) secara berkelanjutan guna mewujudkan visi dan misi perusahaan. Penerapan praktek tata kelola perusahaan yang baik atau good corporate governance (GCG) bagi PT. Bank Mandiri (Persero) Tbk bukan semata mematuhi peraturan perundangundangan yang berlaku, namun juga berarti upaya melakukan inovasi dan penyempurnaan pengelolaan secara berkelanjutan guna meningkatkan kualitas penerapan prinsip-prinsip good corporate governance (GCG). Upaya tersebut dilaksanakan sebagai bagian partisipasi PT. Bank Mandiri (Persero) Tbk dalam menjalankan sistem perbankan yang sehat di Indonesia dengan berlandaskan pada penerapan prinsip-prinsip good corporate governance (GCG).

Berdasarkan hasil observasi awal yang dilakukan pada PT. Bank Mandiri (Persero) Tbk Cabang Bengkulu, diketahui bahwa kebijakan penerapan 
prinsip-prinsip good corporate governance (GCG) yang diterapkan oleh PT. Bank Mandiri (Persero) Tbk Cabang Bengkulu berlandaskan pada peraturan kebijakan prinsip-prinsip good corporate governance (GCG) yang telah ditetapkan oleh pemerintah dan atau PT. Bank Mandiri (Persero) Pusat. Hal ini terlihat dari penerapkan prinsip-prinsip good corporate governance (GCG) yang dikeluarkan oleh PT. Bank Mandiri (Persero) Pusat, jika peraturan dari pusat turun ke cabang, maka semua pengelolah harus mematuhi peraturan yang telah ditetapkan oleh pusat tersebut tanpa terkecuali. Jika dalam penerapannya terdapat pelanggaran, maka akan langsung diberikan sanksi dari pihak PT. Bank Mandiri (Persero) itu sendiri. Penelitian ini bertujuan untuk mengetahui sejauh mana perusahaan PT. Bank Mandiri (Persero) Tbk mengimplementasikan prinsip-prinsip good corporate governance (GCG) dalam menjalankan sistem bisnisnya.

\section{KAJIAN PUSTAKA}

Seperti diketahui perbankan di Indonesia sempat mengalami krisis, hal ini bukan semata-mata diakibatkan oleh krisis ekonomi, tetapi juga diakibatkan oleh belum dilaksanakannya good corporate governance (GCG) dan etika yang melandasinya. Oleh karena itu, usaha mengembalikan kepercayaan kepada dunia perbankan Indonesia melalui restrukturisasi dan rekapitalisasi hanya dapat mempunyai dampak jangka panjang dan mendasar melalui penerapan good corporate governance (GCG) yang baik dalam rangka melindungi kepentingan masyarakat, termasuk ketentuan yang mengatur kewajiban untuk memenuhi modal minimum sesuai dengan kondisi masing-masing bank (Komite Nasional Kebijakan Corporate Governance, 2006). Peraturan Bank Indonesia No. 8/4/PBI/2006 tentang Pelaksanaan Good Corporate Governance Bagi Bank Umum menyatakan bahwa good corporate governance (GCG) adalah suatu tata kelola bank yang menerapkan prinsip prinsip keterbukaan (transparency), akuntabilitas (accountability), pertanggung jawaban (responsibility), independensi (independency), dan kewajaran (fairness).

Implementasi prinsip-prinsip good corporate governance (GCG) perusahaan yang berdomisili di negara-negara berkembang secara konkret dapat memberikan kontribusi untuk memulihkan kepercayaan para kreditor terhadap kinerja suatu perusahaan yang telah dilanda krisis, misalnya di Indonesia. Implementasi prinsip-prinsip good corporate governance (GCG) bertujuan untuk menghasilkan kinerja perusahaan yang efektif dan efisien melalui harmonisasi manajemen perusahaan. Penerapan prinsip good corporate governance (GCG) oleh perusahaan merupakan sebuah pilihan dalam menjalankan kegiatan ekonomi karena good corporate governance (GCG) lebih merupakan suatu etika bisnis dibandingkan suatu keharusan 
dalam penerapannya (Surya dan Yustiavanda, 2006). Prinsip tentang good corporate governance (GCG) yang disusun oleh Organization for Economic Cooperation and Development (OECD) ini menjadi salah satu acuan universal yang menjadi pijakan dalam pengembangan di banyak negara sebagaimana yang dikutip Hinuri (2002), yaitu:

1. Perlindungan terhadap hak-hak pemegang saham.

2. Perlakuan adil bagi seluruh pemegang saham.

3. Peranan stakeholders yang terkait dengan perseroan.

4. Keterbukaan dan transparansi.

5. Tanggung jawab Direksi dan Dewan Komisaris.

Prinsip-prinsip good corporate governance (GCG) menurut Peraturan Bank Indonesia No.8/4/PBI/2006 tentang Pelaksanaan Good Corporate Governance (GCG) bagi Bank Umum, di antaranya transparency, accountability, responsibility, independency dan fairness (TARIF). Hal ini dipertegas oleh Sanim (2011) yang menyatakan bahwa prinsip-prinsip dasar good corporate governance (GCG) yaitu transparency, accountability, responsibility, independency dan fairness. Prinsip-prinsip yang terkandung dalam good corporate governance (GCG) tersebut dapat dijabarkan sebagai berikut:

1. Keterbukaan (Transparency)

Keterbukaan dalam mengemukakan informasi yang material dan relevan serta keterbukaan dalam melaksanakan pengambilan keputusan. Komite Nasional Kebijakan Governance (2006), pedoman pokok pelaksanaannya antara lain sebagai berikut:

a. Perusahaan harus menyediakan informasi secara tepat waktu, memadai, jelas, akurat, dan dapat diperbandingkan serta mudah diakses oleh pemangku kepentingan sesuai dengan haknya.

b. Informasi yang harus diungkapkan meliputi, tetapi tidak terbatas pada visi, misi, sasaran usaha dan strategi perusahaan, kondisi keuangan, susunan dan kompensasi pengurus, pemegang saham pengendali, kepemilikan saham oleh anggota Direksi dan anggota Dewan Komisaris beserta anggota keluarganya dalam perusahaan dan perusahaan lainnya, sistem dan pelaksanaan good corporate governance (GCG) serta tingkat kepatuhannya, dan kejadian penting yang dapat mempengaruhi kondisi perusahaan.

c. Prinsip keterbukaan yang dianut oleh perusahaan tidak mengurangi kewajiban untuk memenuhi ketentuan kerahasiaan perusahaan sesuai dengan peraturan perundang-undangan, rahasia jabatan, dan hak- hak pribadi.

d. Kebijakan perusahaan harus tertulis dan secara proposional dikomunikasikan kepada pemangku kepentingan.

2. Akuntabilitas (Accountability)

Kejelasan fungsi dan pelaksanaan pertanggungjawaban organ bank sehingga pengelolaannya berjalan efektif. Komite Nasional Kebijakan Governance (2006), pedoman pokok pelaksanaannya antara lain sebagai berikut:

a. Perusahaan harus menetapkan rincian tugas dan tanggung jawab masingmasing organ perusahaan dan semua karyawan secara jelas dan selaras 
dengan visi, misi, nilai-nilai perusahaan (corporate values), dan strategi perusahaan.

b. Perusahaan harus meyakini bahwa semua organ perusahaan dan semua karyawan mempunyai kemampuan sesuai dengan tugas, tanggung jawab, dan perannya dalam pelaksanaan good corporate governance (GCG).

c. Perusahaan harus memastikan adanya sistem pengendalian internal yang efektif dalam pengelolaan perusahaan.

d. Perusahaan harus memiliki ukuran kinerja untuk semua jajaran perusahaan yang konsisten dengan sasaran usaha perusahaan, serta memiliki sistem penghargaan dan sanksi.

e. Dalam melaksanakan tugas dan tanggung jawabnya, setiap perusahaan dan semua karyawan harus berpegang pada etika bsinis dan pedoman perilaku yang telah disepakati.

3. Pertanggungjawaban (Responsibility)

Kesesuaian pengelolaan bank dengan peraturan perundang-undangan yang berlaku dan prinsip-prinsip pengelolaan yang sehat. Perusahaan memiliki tanggung jawab untuk mematuhi hukum dan ketentuan/ peraturan yang berlaku, termasuk tanggap lingkungan dimana perusahaan berada. Pedoman pokok pelaksanaannya antara lain sebagai berikut (Komite Nasional Kebijakan Governance, 2006):

a. Organ perusahaan harus berpegang pada prinsip kehati-hatian dan memastikan kepatuhan terhadap peraturan perundang-undangan, anggaran dasar dan peraturan perusahaan.

b. Perusahaan harus melaksanakan tanggung jawab sosial dengan antara lain peduli terhadap masyarakat dan kelestarian lingkungan terutama di sekitar perusahaan dengan membuat perencanaan dan pelaksanaan yang memadai.

4. Independensi (Independency)

Pengelolaan bank secara profesional dan tanpa pengaruh atau tekanan dari pihak manapun. Pedoman pelaksanaannya yaitu:

a. Masing-masing organ perusahaan harus menghindari terjadinya dominasi oleh pihak manapun, tidak terpengaruh oleh kepentingan tertentu, bebas dari benturan kepentingan dan dari segala pengaruh atau tekanan, sehingga pengambilan keputusan dapat dilakukan secara obyektif.

b. Masing-masing organ perusahaan harus melaksanakan fungsi dan tugasnya sesuai dengan anggaran dasar dan peraturan perundang-undangan, tidak saling mendominasi dan atau melempar tanggung jawab antara satu dengan yang lain.

\section{5. $\quad$ Kewajaran (Fairness)}

Keadilan dan kesetaraan dalam memenuhi hak-hak stakeholder yang timbul berdasarkan perjanjian dan peraturan perundang- undangan yang berlaku. Pedoman pokok pelaksanaannya antara lain sebagai berikut:

a. Perusahaan harus memberikan kesempatan kepada pemangku kepentingan untuk memberikan masukan dan menyampaikan pendapat bagi kepentingan perusahaan serta membuka akses terhadap informasi sesuai dengan prinsip transparansi dalam lingkup kedudukan masing-masing. 
b. Perusahaan harus memberikan perlakuan yang setara dan wajar kepada pemangku kepentingan sesuai dengan manfaat dan kontribusi yang diberikan kepada perusahaan.

c. Perusahaan harus memberikan kesempatan yang sama dalam penerimaan karyawan, berkarir dan melaksanakan tugasnya secara profesional tanpa membedakan suku, agama, ras, golongan, gender dan kondisi fisik.

\section{METODE PENELITIAN}

\section{Desain Penelitian}

Penelitian ini merupakan penelitian deskriptif. Penelitian deskriptif adalah penelitian yang menggambarkan dan menjelaskan fenomenafenomena yang terjadi di lapangan (Sugiyono, 2009). Metode deskriptif merupakan proses pemecahan masalah yang diselidiki dengan melukiskan keadaan subjek dan objek penelitian pada saat sekarang berdasarkan faktafakta yang tampak atau bagaimana adanya.

\section{Defenisi Operasional}

- Keterbukan (Transparency) yaitu keterbukaan dalam mengemukakan informasi yang material dan relevan serta keterbukaan dalam melaksanakan pengambilan keputusan. Konstruk ini diukur melalui indikator yang meliputi: 1). Memberikan informasi secara tepat, memadai, jelas, akurat, serta mudah diakses oleh pemangku kepentingan sesuai dengan haknya; 2). Prinsip keterbukaan yang dianut tidak mengurangi kewajiban untuk memenuhi ketentuan kerahasiaan perusahaan sesuai dengan peraturan perundang-undangan; serta 3). Kebijakan tertulis dan secara proposional dikomunikasian kepada pemangku kepentingan.

- Akuntabilitas (Accountability) yaitu kejelasan fungsi dan pelaksanaan pertanggung jawaban organ bank sehingga pengelolaannya berjalan efektif. Konstruk ini diukur melalui indikator yang meliputi: 1). Menetapkan rincian tugas dan tanggung jawab masing-masing karyawan secara jelas dan selaras dengan visi, misi, nilai - nilai perusahaan (corporate values), dan strategi perusahaan; 2). Meyakini semua karyawan mempunyai kemampuan sesuai dengan tugas, tanggung jawab, dan perannya dalam pelaksanaan GCG; 3). Memiliki sistem pengendalian internal yang efektif dalam pengelolaan perusahaan; 4). Memiliki ukuran kinerja untuk semua jajaran perusahaan yang konsisten dengan sasaran usaha perusahaan, serta memiliki sistem penghargaan dan sanksi; serta 5). Dalam melaksanakan tugas dan tanggung jawabnya semua karyawan harus berpegang pada etika bsinis dan pedoman perilaku yang telah disepakati.

- Tanggung jawab (Responsibility) yaitu kesesuaian pengelolaan bank dengan peraturan perundang-undangan yang berlaku dan prinsipprinsip pengelolaan yang sehat. Konstruk ini diukur melalui indikator yang meliputi: 1). Berpegang pada prinsip kehati-hatian dan 
memastikan kepatuhan terhadap peraturan perundang-undangan, anggaran dasar dan peraturan perusahaan; serta 2). Melaksanakan tanggung jawab sosial terhadap masyarakat dan kelestarian lingkungan.

- Independensi (Independency) yaitu pengelolaan bank secara profesional dan tanpa pengaruh atau tekanan dari pihak manapun. Konstruk ini diukur melalui indikator yang meliputi: 1). Menghindari terjadinya dominasi oleh pihak manapun sehingga pengambilan keputusan dapat dilakukan secara obyektif; serta 2). Melaksanakan fungsi dan tugasnya sesuai dengan anggaran dasar dan peraturan perundang-undangan.

- Kewajaran (Fairness) yaitu keadilan dan kesetaraan dalam memenuhi hak-hak stakeholders yang timbul berdasarkan perjanjian dan peraturan perundang-undangan yang berlaku. Konstruk ini diukur melalui indikator yang meliputi: 1). Memberikan kesempatan kepada pemangku kepentingan untuk memberikan masukan dan menyampaikan pendapat bagi kepentingan perusahaan; 2). Memberikan perlakuan yang setara dan wajar kepada pemangku kepentingan sesuai dengan manfaat dan kontribusi yang diberikan kepada perusahaan; serta 3). Memberikan kesempatan yang sama dalam penerimaan karyawan, berkarir dan melaksanakan tugasnya secara profesional tanpa membedakan suku, agama, ras, golongan, gender dan kondisi fisik.

\section{Metode Pengambilan Sampel}

Populasi dalam penelitian ini adalah seluruh karyawan PT. Bank Mandiri (Persero) Tbk Kantor Cabang Bengkulu. Teknik pengambilan sampel dalam penelitian ini adalah simple random sampling yaitu pengambilan sampel dilakukan secara acak tanpa memperhatikan strata yang ada. Teknik ini hanya digunakan jika populasinya homogen, populasi dalam penelitian ini adalah seluruh karyawan PT. Bank Mandiri (Persero) Tbk Kantor Cabang Bengkulu.

\section{Metode Pengumpulan Data}

Metode pengumpulan data yang digunakan berupa data sekuder dan primer. Data sekunder diperoleh melalui buku, artikel-artikel, situs-situs online mengenai jurnal prinsip-prinsip good corporate governance (GCG). Sedangkan data primer didapat melalui penyebaran kuisioner secara langsung dengan cara menemui responden (karyawan). Agar mempermudah responden dalam memberikan jawaban, setiap jawaban atas pertanyaan dikuesioner yang diajukan pada responden diberi skor. Format kuesioner dirancang dengan menggunakan skala likert 1 sampai dengan 5. Skor 1 menunjukkan Sangat Tidak Setuju (STS); 2 Tidak Setuju (TS); 3 Cukup Setuju (CS); 4 Setuju (S); dan 5 Sangat Setuju (SS).

\section{Metode Analisis}

Untuk mengetahui gambaran prinsip-prinsip good corporate governance (GCG) pada PT. Bank Mandiri (Persero) Tbk Cabang Bengkulu melalui prinsipprinsip keterbukaan (transparency), akuntabilitas (accountability), tanggung jawab (responsibility), independensi (independency) dan kewajaran (fairness) menggunakan kuesioner. Kuisioner penelitian yang digunakan merupakan kuesioner tertutup, artinya setiap pertanyaan dalam kuesioner disertai dengan pilihan jawaban. Pilihan jawaban menggunakan skala likert 1 sampai dengan 5. Skor 1 menunjukkan Sangat Tidak Setuju (STS); 2 Tidak Setuju (TS); 
3 Cukup Setuju (CS); 4 Setuju (S); dan 5 Sangat Setuju (SS). Untuk melihat persepsi responden terhadap variabel yang digunakan dalam penelitian ini digunakan metode rata-rata (mean) dan tabel distribusi frekuensi. Untuk menghitung nilai rata-rata (mean) digunakan rumus:

Mean $=\frac{\sum \mathrm{fx}}{\mathrm{N}}$

Dimana:

$\mathrm{f}=$ Frekuensi jawaban responden

$\mathrm{x}=$ Skor jawaban responden

$\mathrm{N}=$ Jumlah sampel

Selanjutnya, dihitung juga skala interval jawaban responden, yang bertujuan untuk memudahkan interpretasi hasil, dengan rumus:

Skala Interval $=\frac{\mathrm{U}-\mathrm{L}}{\mathrm{K}} \quad$ (Sugiyono, 2009)

Dimana:

$\mathrm{U}=$ Skor jawaban tertinggi

$\mathrm{L}=$ Skor jawaban terendah

$\mathrm{k}=$ Jumlah kelas interval

Dari rumus di atas, maka skala interval yang digunakan dalam penelitian ini adalah sebagai berikut:

Dik. Skor jawaban tertinggi (U) $=5$

Skor jawaban terendah (L) $=1$

Jumlah kelas interval $(\mathrm{k}) \quad=5$

$5-1 \quad 4$

Skala Interval $=-\frac{-}{5}=-\frac{-}{5}=0,80$

Jadi jarak (skala) setiap kelas interval sebesar $\mathbf{0 , 8 0}$.

Skala interval tersebut selanjutnya diinterpretasikan ke dalam rata-rata jawaban responden dengan kriteria:

Tabel 1.

Interval Rata-rata Persepsi Responden

\begin{tabular}{|c|c|c|}
\hline No & Interval (Range) & Keterangan \\
\hline 1 & $1.00-1.79$ & Sangat Tidak Baik \\
\hline 2 & $1.80-2.59$ & Tidak Baik \\
\hline 3 & $2.60-3.39$ & Cukup Baik \\
\hline 4 & $3.40-4.19$ & Baik \\
\hline 5 & $4.20-5.00$ & Sangat Baik \\
\hline
\end{tabular}

Sumber: Sugiyono (2009)

HASIL PENELITIAN DAN PEMBAHASAN 


\section{Persepsi Responden Terhadap Variabel Prinsip Keterbukaan}

(Transparency)

Persepsi responden mengenai prinsip keterbukaan (transparency) mendapatkan nilai 3.71. Hal ini menunjukkan bahwa implementasi prinsip keterbukaan (transparency) pada PT. Bank Mandiri (Persero) Tbk Cabang Bengkulu sudah berjalan dengan baik. Jika dilihat dari pernyataan responden mengenai prinsip keterbukaan (transparency), yang mendapatkan nilai rata-rata tertinggi yaitu sebesar 3.87 (baik). Artinya, implementasi prinsip keterbukaan (transparency) pada PT. Bank Mandiri (Persero) Tbk Cabang Bengkulu sudah berjalan dengan baik, hal ini terlihat dari kebijakan PT. Bank Mandiri (Persero) Tbk Cabang Bengkulu tertulis dan secara proposional selalu dikomunikasian kepada pemangku kepentingan.

2. Persepsi Responden Terhadap Variabel Prinsip Akuntabilitas (Accountability)

Persepsi responden mengenai prinsip akuntabilitas (accountability) mendapatkan nilai 3.86. Hal ini menunjukkan bahwa implementasi prinsip akuntabilitas (accountability) pada PT. Bank Mandiri (Persero) Tbk Cabang Bengkulu sudah berjalan dengan baik. Jika dilihat dari pernyataan responden mengenai akuntabilitas (accountability), yang mendapatkan nilai rata-rata tertinggi yaitu sebesar 4.06 (baik). Artinya, implementasi prinsip akuntabilitas (accountability) pada PT. Bank Mandiri (Persero) Tbk Cabang Bengkulu sudah berjalan dengan baik. Hal ini terlihat dari pelaksanakan tugas dan tanggung jawab semua karyawan PT. Bank Mandiri (Persero) Tbk Cabang Bengkulu yang berpegang pada etika bsinis dan pedoman perilaku yang telah disepakati.

3. Persepsi Responden Terhadap Variabel Prinsip Tanggung Jawab (Responsibility)

Persepsi responden mengenai prinsip tanggung jawab (responsibility) mendapatkan nilai 3.76. Hal ini menunjukkan bahwa implementasi prinsip tanggung jawab (responsibility) pada PT. Bank Mandiri (Persero) Tbk Cabang Bengkulu sudah berjalan dengan baik. Jika dilihat dari pernyataan responden mengenai prinsip tanggung jawab (responsibility), yang mendapatkan nilai rata-rata tertinggi sebesar 3.81 (baik). Artinya, implementasi prinsip tanggung jawab (responsibility) pada PT. Bank Mandiri (Persero) Tbk Cabang Bengkulu sudah berjalan dengan baik. Hal ini terlihat dari PT. Bank Mandiri (Persero) Tbk Cabang Bengkulu berpegang pada prinsip kehati-hatian dan memastikan kepatuhan terhadap peraturan perundang-undangan, anggaran dasar dan peraturan perusahaan.

4. Persepsi Responden Terhadap Variabel Prinsip Independensi (Independency)

Persepsi responden mengenai prinsip independensi (independency) mendapatkan nilai 3.67. Hal ini menunjukkan bahwa implementasi 
prinsip independensi (independency) pada PT. Bank Mandiri (Persero) Tbk Cabang Bengkulu sudah berjalan dengan baik. Jika dilihat dari pernyataan responden mengenai independensi (independency), yang mendapatkan nilai rata-rata tertinggi sebesar 3.75 (baik). Artinya, implementasi prinsip independensi (independency) pada PT. Bank Mandiri (Persero) Tbk Cabang Bengkulu sudah berjalan dengan baik. Hal ini terlihat dari PT. Bank Mandiri (Persero) Tbk Cabang Bengkulu melaksanakan fungsi dan tugasnya sesuai dengan anggaran dasar dan peraturan perundang-undangan.

\section{Persepsi Responden Terhadap Variabel Prinsip Kewajaran} (Fairness)

Persepsi responden mengenai prinsip kewajaran (fairness) mendapatkan nilai 3.86. Hal ini menunjukkan bahwa implementasi prinsip kewajaran (fairness) pada PT. Bank Mandiri (Persero) Tbk Cabang Bengkulu sudah berjalan dengan baik. Jika dilihat dari pernyataan responden mengenai prinsip kewajaran (fairness), yang mendapatkan nilai rata-rata tertinggi sebesar 4.00 (baik). Artinya, implementasi prinsip kewajaran (fairness) pada PT. Bank Mandiri (Persero) Tbk Cabang Bengkulu sudah berjalan dengan baik. Hal ini terlihat dari PT. Bank Mandiri (Persero) Tbk Cabang Bengkulu selalu memberikan kesempatan kepada pemangku kepentingan untuk memberikan masukan dan menyampaikan pendapat bagi kepentingan perusahaan.

\section{PEMBAHASAN}

Pada dasarnya industri perbankan merupakan suatu badan usaha yang bergerak dalam bidang keuangan, yang kegiatannya menghimpun dana dari masyarakat dalam bentuk simpanan dan menyalurkannya kepada masyarakat dalam bentuk kredit dan atau bentuk-bentuk lainnya dalam rangka meningkatkan taraf hidup rakyat banyak. Industri perbankan mempunyai regulasi yang lebih ketat dibandingkan dengan industri lainnya. Kebutuhan untuk menerapkan prinsip-prinsip good corporate governance (GCG) dirasakan sangat kuat dalam industri perbankan. Situasi eksternal dan internal perbankan semakin kompleks dengan resiko kegiatan usaha perbankan sangat beragam. Penerapan prinsip-prinsip good corporate governance (GCG) selain untuk meningkatkan daya saing bank itu sendiri, juga lebih memberikan perlindungan kepada masyarakat. Penerapan prinsipprinsip good corporate governance (GCG) menjadi suatu kepercayaan mengingat industri perbankan mengelola dana publik (nasabah).

Berdasarkan dari pernyataan responden mengenai implemtasi prinsipprinsip good corporate governance (GCG) pada PT. Bank Mandiri (Persero) Tbk. Cabang Bengkulu yang terdiri dari prinsip keterbukaan (transparency), prinsip akuntabilitas (accountability), prinsip tanggung jawab (responsibility), 
prinsip independensi (independency) dan prinsip kewajaran (fairness). Sebagaiman hasil nilai rata-rata persepsi responden berikut ini:

Tabel 2.

Pernyataan Responden Mengenai Implementasi Prinsip-prinsip Good Corporate Governance (GCG) pada PT. Bank Mandiri (Persero) Tbk. Cabang Bengkulu

\begin{tabular}{|c|c|c|c|c|}
\hline $\begin{array}{l}\mathbf{N} \\
\mathbf{o}\end{array}$ & $\begin{array}{c}\text { Prinsip- } \\
\text { Prinsip GCG }\end{array}$ & $\begin{array}{c}M e a \\
n\end{array}$ & $\begin{array}{l}\text { Interva } \\
\text { l Rata- } \\
\text { rata }\end{array}$ & $\begin{array}{l}\text { Kriteri } \\
\quad \mathbf{a}\end{array}$ \\
\hline 1 & $\begin{array}{l}\text { Keterbukaan } \\
\text { (Transparency) }\end{array}$ & 3.71 & $\begin{array}{c}3.40- \\
4.19 \\
\end{array}$ & Baik \\
\hline 2 & $\begin{array}{l}\text { Akuntabilitas } \\
\text { (Accountability }\end{array}$ & 3.86 & $\begin{array}{c}3.40- \\
4.19\end{array}$ & Baik \\
\hline 3 & $\begin{array}{l}\text { Tanggung } \\
\text { Jawab } \\
\text { (Responsibility) }\end{array}$ & 3.76 & $\begin{array}{c}3.40- \\
4.19\end{array}$ & Baik \\
\hline 4 & $\begin{array}{l}\text { Independensi } \\
\text { (Independency) }\end{array}$ & 3.67 & $\begin{array}{c}3.40- \\
4.19\end{array}$ & Baik \\
\hline 5 & $\begin{array}{l}\text { Kewajaran } \\
\text { (Fairness) }\end{array}$ & 3.86 & $\begin{array}{c}3.40- \\
4.19 \\
\end{array}$ & Baik \\
\hline \multicolumn{2}{|c|}{ Rata-rata } & 3.77 & $\begin{array}{c}3.40- \\
4.19\end{array}$ & Baik \\
\hline
\end{tabular}

Sumber: Hasil Penelitian 2018, data di olah

Berdasarkan Tabel 2, diketahui bahwa implemtasi prinsip-prinsip good corporate governance (GCG) pada PT. Bank Mandiri (Persero) Tbk. Cabang Bengkulu sudah berjalan baik dengan nilai rata-rata pernyataan responden mengenai prinsip keterbukaan (transparency), prinsip akuntabilitas (accountability), prinsip tanggung jawab (responsibility), prinsip independensi (independency) dan prinsip kewajaran (fairness) sebesar 3.77 (baik). Implemtasi prinsip-prinsip good corporate governance (GCG) pada PT. Bank Mandiri (Persero) Tbk. Cabang Bengkulu yang baik tentunya dapat meningkatkan kinerja PT. Bank Mandiri (Persero) Tbk. Cabang Bengkulu tersebut.

Peraturan Bank Indonesia No. 8/4/PBI/2006 tentang Pelaksanaan Good Corporate Governance Bagi Bank Umum menyatakan bahwa good corporate governance (GCG) adalah suatu tata kelola bank yang menerapkan prinsip prinsip keterbukaan (transparency), akuntabilitas (accountability), pertanggung jawaban (responsibility), independensi (independency), dan kewajaran (fairness). Anshori (2007) juga mengatakan bahwa pelaksanaan good corporate governance (GCG) pada industri perbankan harus senantiasa berlandaskan pada lima prinsip dasar tersebut. Keterbukaan (transparency), dimaksudkan keterbukaan dalam mengemukakan informasi yang material dan relevan serta keterbukaan dalam melaksanakan pengambilan keputusan (Komite Nasional Kebijakan Governance, 2006). Hasil penelitian menunjukkan bahwa implementasi prinsip-prinsip good corporate 
governance (GCG) yang dilihat dari implementasi prinsip keterbukaan (transparency) pada PT. Bank Mandiri (Persero) Tbk. Cabang Bengkulu sudah berjalan dengan baik dengan nilai rata-rata pernyataan sebesar 3.71. Hal tersebut terlihat terutama dari kebijakan PT. Bank Mandiri (Persero) Tbk Cabang Bengkulu tertulis dan secara proposional selalu dikomunikasian kepada pemangku kepentingan.

Selanjutnya, akuntabilitas (accountability) yang merupakan kejelasan fungsi dan pelaksanaan pertanggungjawaban organ bank sehingga pengelolaannya berjalan efektif (Komite Nasional Kebijakan Governance, 2006). Hasil penelitian menunjukkan bahwa implementasi prinsip-prinsip good corporate governance (GCG) yang dilihat dari penerapan prinsip akuntabilitas (accountability) pada PT. Bank Mandiri (Persero) Tbk Cabang Bengkulu sudah berjalan dengan baik dengan nilai rata-rata pernyataan 3.86. Hal tersebut terlihat terutama dari pelaksanakan tugas dan tanggung jawab semua karyawan PT. Bank Mandiri (Persero) Tbk Cabang Bengkulu yang berpegang pada etika bsinis dan pedoman perilaku yang telah disepakati. Pertanggungjawaban (responsibility) merupakan kesesuaian pengelolaan bank dengan peraturan perundang-undangan yang berlaku dan prinsipprinsip pengelolaan yang sehat. Perusahaan memiliki tanggung jawab untuk mematuhi hukum dan ketentuan/ peraturan yang berlaku, termasuk tanggap lingkungan dimana perusahaan berada (Komite Nasional Kebijakan Governance, 2006). Hasil penelitian menunjukkan bahwa implementasi prinsip-prinsip good corporate governance (GCG) yang dilihat dari penerapan prinsip tanggung jawab (responsibility) pada PT. Bank Mandiri (Persero) Tbk Cabang Bengkulu sudah berjalan dengan baik dengan nilai rata-rata pernyataan 3.76. Hal tersebut terlihat terutama dari PT. Bank Mandiri (Persero) Tbk Cabang Bengkulu berpegang pada prinsip kehati-hatian dan memastikan kepatuhan terhadap peraturan perundang-undangan, anggaran dasar dan peraturan perusahaan.

Kemudian, independensi (independency) merupakan pengelolaan bank secara profesional dan tanpa pengaruh atau tekanan dari pihak manapun (Komite Nasional Kebijakan Governance, 2006). Hasil penelitian menunjukkan bahwa implementasi prinsip-prinsip good corporate governance (GCG) yang dilihat dari penerapan prinsip independensi (independency) pada PT. Bank Mandiri (Persero) Tbk Cabang Bengkulu sudah berjalan dengan baik dengan nilai rata-rata pernyataan 3.67. Hal tersebut terlihat terutama dari PT. Bank Mandiri (Persero) Tbk Cabang Bengkulu melaksanakan fungsi dan tugasnya sesuai dengan anggaran dasar dan peraturan perundang-undangan. Serta kewajaran (fairness) yang merupakan keadilan dan kesetaraan dalam memenuhi hak-hak stakeholder yang timbul berdasarkan perjanjian dan peraturan perundang-undangan yang berlaku (Komite Nasional Kebijakan Governance, 2006). Hasil penelitian menunjukkan bahwa implementasi prinsip-prinsip good corporate governance (GCG) yang dilihat dari penerapan prinsip kewajaran (fairness) pada PT. Bank Mandiri (Persero) Tbk Cabang Bengkulu sudah berjalan dengan baik dengan nilai rata-rata pernyataan 3.86. Hal tersebut terlihat terutama PT. Bank Mandiri (Persero) Tbk Cabang Bengkulu selalu memberikan kesempatan kepada pemangku kepentingan 
untuk memberikan masukan dan menyampaikan pendapat bagi kepentingan perusahaan.

Implementasi prinsip-prinsip good corporate governance (GCG) sangat penting dalam industri perbankan. William A. Lovette mengatakan "Bank and financial institution collect money and deposit from all elements of society and invest these fund in loans, securities and various other production assets" (Nasution, 2007). Oleh karena itu, dalam menjalankan fungsi utama bank, yaitu untuk memobilisasi dana masyarakat dan menyalurkan dana tersebut dalam bentuk kredit kepada penggunanya atau investasi yang efektif dan efisien, maka perlu didukung dengan peraturan yang cukup yang tidak terpisahkan dari prinsip-prinsip good corporate governance (GCG). Sebagai lembaga intermediasi dan lembaga kepercayaan, dalam melaksanakan kegiatan usahanya bank harus menganut prinsip keterbukaan (transparacy), memiliki ukuran kinerja dari semua jajaran bank berdasarkan ukuran-ukuran yang konsisten dengan corporate value, sasaran usaha dan strategi bank sebagai pecerminan akuntabilitas bank (accountability), berpegang pada prudential banking practices dalam menjamin dilaksanakannya ketentuan yang berlaku sebagai wujud tanggung jawab bank (responsibility), objektif dan bebas dari tekanan pihak manapun dalam penambilan keputusan (independency), serta senantiasa memperhatikan stakeholders berdasarkan azas kesetaraan dan kewajaran (fairness). Oleh sebab itu dalam penerapan good corporate governance (GCG) suatu perbankan harus melaksanakan prinsip-prinsip tersebut.

Beberapa peraturan yang telah dikeluarkan berkaitan dengan penerapan prinsip good corporate governance (GCG) antara lain Peraturan OJK No. 55/POJK.03/2016 tentang penerapan tata kelola bagi bank umum. Tujuan utama dari peraturan ini adalah berbagai upaya perwujudan good corporate governance (GCG) dengan mengeliminasi kemungkinan penyimpangan opersional bank yang dilakukan oleh Direksi dan Komisaris, maupun pemegang saham. Peraturan lainnya yang dikeluarkan berkaitan dengan kebutuhan peningkatan good corporate governance (GCG) adalah Peraturan OJK No.17/POJK.03/2014. POJK tersebut mewajibkan bank untuk menetapkan wewenang dan tanggung jawab yang jelas pada setiap jenjang jabatan yang terkait dengan penerapan manajemen risiko. Selain itu diatur juga mengenai kewenangan dan tanggung jawab direksi dan komisaris yang harus dilakukan terkait penerapan manajemen risiko tersebut.

\section{KESIMPULAN}

Berdasarkan hasil penelitian dan pembahasan, dapat diambil kesimpulan yakni implementasi prinsip-prinsip good corporate governance (GCG) pada PT. Bank Mandiri (Persero) Tbk. Cabang Bengkulu sudah berjalan baik dengan nilai rata-rata pernyataan sebesar 3.77 (baik). Kesimpulan akhir yang dapat ditarik dalm penelitian ini yaitu sebagai berikut: 
1. Implementasi prinsip keterbukaan (transparency) pada PT. Bank Mandiri (Persero) Tbk. Cabang Bengkulu sudah baik dengan nilai rata-rata pernyataan sebesar 3.71 (baik). Hal tersebut terlihat terutama dari kebijakan PT. Bank Mandiri (Persero) Tbk. Cabang Bengkulu tertulis dan secara proposional selalu dikomunikasian kepada pemangku kepentingan.

2. Implementasi prinsip akuntabilitas (accountability) pada PT. Bank Mandiri (Persero) Tbk. Cabang Bengkulu sudah baik dengan nilai rata-rata pernyataan 3.86 (baik). Hal tersebut terlihat terutama dari pelaksanakan tugas dan tanggung jawab semua karyawan PT. Bank Mandiri (Persero) Tbk. Cabang Bengkulu yang berpegang pada etika bsinis dan pedoman perilaku yang telah disepakati.

3. Implementasi prinsip tanggung jawab (responsibility) pada PT. Bank Mandiri (Persero) Tbk. Cabang Bengkulu sudah baik dengan nilai rata-rata pernyataan 3.76 (baik). Hal tersebut terlihat terutama dari PT. Bank Mandiri (Persero) Tbk. Cabang Bengkulu berpegang pada prinsip kehati-hatian dan memastikan kepatuhan terhadap peraturan perundang-undangan, anggaran dasar dan peraturan perusahaan.

4. Implementasi prinsip independensi (independency) pada PT. Bank Mandiri (Persero) Tbk. Cabang Bengkulu sudah baik dengan nilai rata-rata pernyataan 3.67 (baik). Hal tersebut terlihat terutama dari PT. Bank Mandiri (Persero) Tbk. Cabang Bengkulu melaksanakan fungsi dan tugasnya sesuai dengan anggaran dasar dan peraturan perundang-undangan.

5. Implementasi prinsip kewajaran (fairness) pada PT. Bank Mandiri (Persero) Tbk. Cabang Bengkulu sudah baik dengan nilai rata-rata pernyataan 3.86 (baik). Hal tersebut terlihat terutama PT. Bank Mandiri (Persero) Tbk. Cabang Bengkulu selalu memberikan kesempatan kepada pemangku kepentingan untuk memberikan masukan dan menyampaikan pendapat bagi kepentingan perusahaan.

\section{SARAN}

Berdasarkan hasil penelitian mengenai implemtasi prinsip-prinsip good corporate governance (GCG) pada PT. Bank Mandiri (Persero) Tbk. Cabang Bengkulu Bengkulu, maka peneliti memberikan beberapa saran yang dapat dipertimbangkan berkaitan dengan hasil penelitian yakni:

1. Implemtasi prinsip-prinsip good corporate governance (GCG) pada PT. Bank Mandiri (Persero) Tbk. Cabang Bengkulu menjadi sebuah keharusan karena aset fisik dari perbankan adalah nasabahnya, dengan mengimplemtasikan prinsip-prinsip good corporate governance (GCG) secara baik dapat mendorong PT. Bank Mandiri (Persero) Tbk. Cabang Bengkulu untuk lebih maju lagi dan dapat bersaing dengan perbankan lainnya. Oleh karena itu kedepan diharapakan PT. Bank Mandiri (Persero) Tbk. Cabang Bengkulu dapat mempertahankan dan lebih baik lagi dalam mengimplementasikan prinsip-prinsip good corporate governance (GCG) yang meliputi keterbukaan (transparency), akuntabilitas (accountability), tanggung jawab (responsibility), independensi (independency) dan kewajaran (fairness). 
2. PT. Bank Mandiri (Persero) Tbk. Cabang Bengkulu diharapkan tidak mengurangi kewajiban untuk memenuhi ketentuan kerahasiaan perusahaan sesuai dengan peraturan perundang-undangan, menetapkan rincian tugas dan tanggung jawab masing-masing karyawan secara jelas dan selaras dengan visi, misi, nilai-nilai perusahaan (corporate value's), dan strategi perusahaan.

3. PT. Bank Mandiri (Persero) Tbk. Cabang Bengkulu diharapkan terus melaksanakan tanggung jawab sosial terhadap masyarakat dan kelestarian lingkungan dengan baik, menghindari terjadinya dominasi oleh pihak manapun sehingga pengambilan keputusan dapat dilakukan secara obyektif serta tentunya memberikan kesempatan yang sama dalam penerimaan karyawan, berkarir dan melaksanakan tugasnya secara profesional tanpa membedakan suku, agama, ras, golongan, gender dan kondisi fisik.

\section{DAFTAR PUSTAKA}

Anshori, A. G, (2007). Payung Hukum Perbankan (UU di Bidang Perbankan, Fatwa DSN-MUI, dan Peraturan Bank Indonesia). Yogyakarrta: UII Press.

Hinuri, H, (2002). The Essence of Good Corporate Governance: Konsep dan Implementasi Pada Perusahaan Publik dan Korporasi Indonesia. Jakarta: Yayasan Pendidikan Pasar Modal Indonesia \& Sinergi Communication.

Komite Nasional Kebijakan Governance (KNKG), (2006). Pedoman Umum Good Corporate Governance Indonesia.

Nasution, B, (2007). Hukum Kegiatan Ekonomi. Bandung: Books Terrace \& Library.

Peraturan Bank Indonesia (PBI) No. 8/4/PBI/2006 Tentang Pelaksanaan Prinsip-Prinsip Good Corporate Governance (GCG) Bagi Bank Umum.

Peraturan Otoritas Jasa Keuangan (OJK) No. 55/POJK.03/2016 Tentang Penerapan Tata Kelola Bagi Bank Umum.

Peraturan Otoritas Jasa Keuangan (OJK) No. 17/POJK.03/2014 Tentang Penerapan Manajemen Risiko Terintegrasi Bagi Konglomerasi Keuangan.

Sanim, B. 2011. The Golden Dynamic Triangle of Control System in PT Bank Rakyat Indonesia, Tbk. Bogor: PT Penerbit IPB Press.

Sugiyono. 2009. Metode Penelitian Bisnis. Bandung: Alfabeta.

Surya, I., dan Yustiavanda, I, (2006). Penerapan Good Corporate Governance Mengesampingkan Hak-Hak Istimewa Demi Kelangsungan Usaha. Jakarta: Kencana. 